\title{
Breeding of Black Soybean with Green Cotyledon and Four Recessive Alleles for Lipoxygenase, Kunitz Trypsin Inhibitor, Lectin, and Stachyose
}

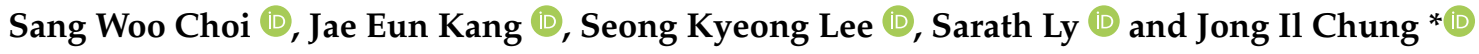 \\ Department of Agronomy, Gyeongsang National University, JinJu 52828, Korea; cswv1004@naver.com (S.W.C.); \\ w0414s@naver.com (J.E.K.); dorries_records@naver.com (S.K.L.); sarathly16@gmail.com (S.L.) \\ * Correspondence: jongil@gnu.ac.kr; Tel.: +82-55-772-1872
}

Citation: Choi, S.W.; Kang, J.E.; Lee, S.K.; Ly, S.; Chung, J.I. Breeding of Black Soybean with Green Cotyledon and Four Recessive Alleles for Lipoxygenase, Kunitz Trypsin Inhibitor, Lectin, and Stachyose. Agronomy 2021, 11, 309. https:// doi.org/10.3390/agronomy11020309

Academic Editor: Hamid Khazaei

Received: 13 January 2021

Accepted: 3 February 2021

Published: 10 February 2021

Publisher's Note: MDPI stays neutral with regard to jurisdictional claims in published maps and institutional affiliations.

Copyright: (c) 2021 by the authors. Licensee MDPI, Basel, Switzerland. This article is an open access article distributed under the terms and conditions of the Creative Commons Attribution (CC BY) license (https:// creativecommons.org/licenses/by/ $4.0 /)$.

\begin{abstract}
Anthocyanins from the black soybean seed coat are known to have many pharmaceutical effects. However, black soybean seed contains antinutritional factors such as lipoxygenase, Kunitz trypsin inhibitor (KTI), lectin, and stachyose. The genetic removal of these components will improve the nutritional value of black soybean seed. The objective of this research was to breed a soybean strain with the black seed coat color, green cotyledon color, and tetra recessive allele (lox1lox2lox3/lox1lox2lox3-ti/ti-le/le-rs2/rs2) for lipoxygenase, KTI, lectin, and stachyose components. Eight parents were used to breed the tetra null strain. Analysis of lipoxygenase, KTI, lectin, and stachyose components in mature seeds was conducted by SDS-PAGE, Western blot, and HPLC. The soybean line with the black seed coat color, the green cotyledon color, a large seed size, and tetra recessive alleles has purple flowers, a determinate growth habit, and brown pods at maturity. The stem height of the breeding line was $52.3 \mathrm{~cm}$. The 100-seed weight of the breeding line was $35.2 \mathrm{~g}$ and the yield (Ton/ha) was 2.50. The stachyose content of the breeding line was $3.30 \mathrm{~g} / \mathrm{kg}$. This is the first soybean strain with the black seed coat color, the green cotyledon color, a large seed size, and tetra null alleles (lox1lox2lox3/lox1lox2lox3-ti/ti-le/le-rs2/rs2, low content of stachyose, free of lipoxygenase, KTI, and lectin proteins).
\end{abstract}

Keywords: lipoxygenase; KTI; lectin; stachyose; tetra null; black soybean

\section{Introduction}

Black soybean (Glycine max (L.) Merr.) has been widely cultivated in Korea, China, and Japan for about 5000 years. Black soybean with green cotyledon has been known as a medicinal food by the health-promoting benefits. Anthocyanins are abundant in the seed coat of black soybean. Anthocyanins are known to have many health-promoting effects such as antioxidant effects, reduction in the risk of coronary heart disease, regulation of adhesion molecules, and protection from ischemia and reperfusion heart injury [1-3]. However, lipoxygenase protein, Kunitz trypsin inhibitor (KTI) protein, lectin protein, and stachyose components exist in the seed of black soybean. These components are mainly responsible for reducing the nutritional value of unprocessed soybeans.

Mature soybean seeds contain lipoxygenase protein, which accounts for approximately $1 \sim 2 \%$ of the total protein. Lipoxygenases can be isolated as three isoenzymatic forms and catalyze the hydroperoxidation of polyunsaturated fatty acids, such as linoleic (18:2) and linolenic (18:3) acids. Lipoxygenases play a role in the production of undesirable grassy and beany aromas and flavors in foods containing soybean. Three lipoxygenases (Lox1, Lox2, and Lox3) exist in mature soybean seeds [4]. Soybean strains free of $\operatorname{Lox} 1[5,6], \operatorname{Lox} 2[7,8]$, and Lox3 [9] have been identified, and the inheritance of the activity of each of the enzymes was studied. The absence of each enzyme is under the control of three null alleles, lox1, lox2, and lox3, which are inherited as simple recessive alleles. Genetic studies demonstrated that the Lox1 and Lox2 loci were found to be in a tight genetic linkage on chromosome 13, 
with lox 1 and lox 2 mutant alleles being in the repulsion phase since they were identified in an independent germplasm [6-8]. The Lox3 locus, on chromosome 15, segregates independently of Lox1 and Lox2 [7,8,10]. Extra costs are needed to inactivate lipoxygenase activity by heat at the industrial level, and soybean cultivars that are lipoxygenase-free are better accepted. A few lipoxygenase-free soybean cultivars have been developed [11].

Kunitz trypsin inhibitor (KTI) protein from soybean seeds was first isolated and crystallized in [12]. KTI protein is a small and non-glycosylated protein containing 181 amino acid residues with $21.5 \mathrm{kDa}$ and strongly inhibits trypsin, thus reducing the food intake by diminishing digestion and absorption. Two soybean accessions (PI157440 and PI196168) lacking the KTI protein from the United States Department of Agriculture (USDA) Soybean Germplasm Collection have been identified [13]. Different forms of $\mathrm{Ti}^{\mathrm{a}}$, $T i^{\mathrm{b}}, T i^{\mathrm{c}}$, and $T i^{\mathrm{d}}$ have been identified at a single locus with a codominant multiple allelic series [13-15]. Orf and Hymowitz [13] have identified a recessive allele designated $t i$ that lacks soybean KTI protein. Crude protein from the titi genotype had a 30\% to 50\% reduction in trypsin inhibitor activity compared with the TiTi genotype. The Ti gene was found to be on chromosome 8 .

Soybean lectin protein, consisting of four similar subunits that each have a molecular weight of $30 \mathrm{kDa}$, is a glycoprotein that specifically binds galactose or $\mathrm{N}$-acetylgalactosamine. The concentration of soybean lectin protein ranges from about $1 \% \sim 2 \%$ on seed dry mass [16]. Soybean lectin protein with $120 \mathrm{kDa}$ molecular weight is a major antinutritional element and can strongly inhibit degradation by proteases under in vitro and in vivo conditions [17]. The biological activity of soybean lectin protein can be reduced by proper heating, but considerable biological activity is found after heating. This residual soybean lectin protein causes the negative effects on the nutritional quality of the soybean protein, such as the digestion and absorption of nutrients [18]. Orf et al. [19] identified that soybean seed lectin was controlled by a single gene designated Le (le) and the lele genotype, resulting in the lack of lectin in mature seed. The Ti gene was found to be on chromosome 2 . Independent inheritance between $L e$ and $T i$ loci was identified $[13,20,21]$. Triple null recessive genotypes ( $t$ i/ti-le/le-p34/p34) in soybeans were developed [22].

Stachyose is the primary carbohydrate in soybean seed. Content of stachyose ranges from 14 to $41 \mathrm{~g} / \mathrm{kg}$ on a dry-weight basis and is environmentally stable but genotypically dependent $[23,24]$. Because stachyose is not readily digestible and causes flatulence or diarrhea for non-ruminant animals, stachyose is considered as an undesirable sugar in soybean seed [25]. Skoneczka et al. [26] identified that stachyose content was controlled by a single gene or a major Quantitative Trait Loci (QTL). The raffinose synthase 2 gene (RS2, Glyma06g18890) is the key in raffinose and stachyose biosynthesis. The rs2 allele (containing three-bp deletions in the RS2 gene) results in low raffinose and stachyose in soybean line PI200508 [27]. The RS2 locus is located in chromosome 6. No negative effects on traits of field emergence, seed yield, maturity, height, and fatty acid content between lines derived from PI200508 containing the reduced stachyose content and wild types were reported [28]. A heat treatment is required to reduce the activity of lipoxygenase, KTI, and lectin proteins that exist in mature raw black seeds. Additionally, this step may require energy costs as well as lower amino acid availability, and it alters the physical properties of soybean proteins. The genetic removal of these components could be an alternative to this problem. So far, only a few articles about soybean breeding in the line with the black seed coat color, the green cotyledon color, and free of both antinutritional and allergenic factors have been published. A soybean cultivar 'Gaechuck\#1' that has the traits of black seed coat color, green cotyledon color, lipoxygenase-2,3-free, and KTI proteins-free was developed [11]. The genotype of 'Gaechuck\#1' was Lox1lox2lox3/Lox1lox2lox3-ti/ti. A soybean strain with the black seed coat color, the green cotyledon color, KTI protein-free, and lectin protein-free was developed [29]. A soybean possessing a yellow seed coat color and triple recessive alleles $(t i / t i-l e / l e-p 34 / p 34)$ for KTI, lectin, and P34 proteins was developed [22]. The objective of this research was to breed a new black soybean line with 
green cotyledon and tetra recessive alleles (lox1lox2lox3/lox1lox2lox3-ti/ti-le/le-rs2/rs2) for lipoxygenase, KTI, lectin, and stachyose components.

\section{Materials and Methods}

\subsection{Breeding Materials}

Eight parents were used to breed a new black soybean line with green cotyledon and tetra recessive alleles. 'Seoritae' (landrace variety) was used as a parent for traits of large seed size, black seed coat color, and green cotyledon color. The PI506592 parent was used to introduce the traits for black seed coat color and large seed size into a tetra null strain. PI408251 (lox1 allele), PI86023 (lox2 allele), and PI417458 (lox3 allele) parents were used for the lipoxygenase protein-free breeding line. For the breeding line without KTI and lectin proteins, PI157440 ( $t i$ allele) and PI548392 (le allele) parents were used, respectively. The PI200508 (rs2 allele) parent was used for the breeding line with a low stachyose content. Phenotypes of eight parents for these four components, seed coat, and cotyledon are presented in Table 1.

Table 1. Phenotypes of the eight parents used in this experiment for lipoxygenase, Kunitz trypsin inhibitor (KTI), lectin, stachyose, seed coat, and cotyledon (Bold letter: recessive trait).

\begin{tabular}{|c|c|c|c|c|c|c|c|c|}
\hline \multirow{2}{*}{$\begin{array}{l}\text { Cultivar/ } \\
\text { Germplasm }\end{array}$} & \multicolumn{3}{|c|}{ Lipoxygenase } & \multirow{2}{*}{ KTI } & \multirow{2}{*}{ Lectin } & \multirow{2}{*}{ Stachyose } & \multirow{2}{*}{ Seed coat } & \multirow{2}{*}{ Cotyledon } \\
\hline & 1 & 2 & 3 & & & & & \\
\hline Seoritae & Present & Present & Present & Present & Present & Normal & Black & Green \\
\hline PI408251 & Absent & Present & Present & Present & Present & Normal & Black & Yellow \\
\hline PI86023 & Present & Absent & Present & Present & Present & Normal & Green & Yellow \\
\hline PI417458 & Present & Present & Absent & Present & Present & Normal & Yellow & Yellow \\
\hline PI157440 & Present & Present & Present & Absent & Present & Normal & Yellow & Yellow \\
\hline PI548392 & Present & Present & Present & Present & Absent & Normal & Black & Yellow \\
\hline PI200508 & Present & Present & Present & Present & Present & Low & Yellow & Yellow \\
\hline PI506592 & Present & Present & Present & Present & Present & Normal & Black & Yellow \\
\hline
\end{tabular}

\subsection{Breeding Scheme}

Recessive alleles for lox $1, \operatorname{lox} 2$, and lox 3 were determined by identifying absence of lipoxygenase- 1, 2, and 3 protein using SDS electrophoresis. Recessive alleles of $t i$ and $l e$ were determined by confirming the absence of KTI and lectin proteins using the Western blot technique. The $r s 2$ allele, which determines the low stachyose content, was identified by examining the content of stachyose by the HPLC method. The genotype of lox1/lox1lox2/lox2 (lipoxygenase-1,2 protein-free) was selected from the population derived from the cross of PI408251 and PI86023. The lox1/lox1-lox2/lox2-lox3/lox3 genotype (lipoxygenase$1,2,3$ protein-free) was developed from the cross of the lox1/lox1-lox2/lox2 genotype and PI417458. From a cross of the 'Seoritae' cultivar and the lox1lox2lox3/lox1lox2lox3 genotype, a strain possessing the lox1lox2lox3/lox1lox2lox3 genotype, a black seed coat, and green cotyledon was developed. A lox1lox2lox3/lox1lox2lox3 plant with a black seed coat and cotyledon was crossed to the PI200508 parent ( $r s 2 / r s 2$ genotype) to select a strain with a black seed coat, green cotyledon, lipoxygenase-free, and low content of stachyose (lox1lox2lox3/lox1lox2lox3-rs2/rs2 genotype, lipoxygenase protein-free, and low content of stachyose). The genotype of $t i / t i-l e / l e$ (KTI-free and lectin proteins-free) was developed from the cross of PI157440 and PI548392 parents. From a cross of the 'Seoritae' cultivar and the $t i / t i-l e / l e$ genotype, a strain with a black seed coat, green cotyledon, and the $t i / t i-l e / l e$ genotype was developed. The strain with a black seed coat, green cotyledon, a large seed size, and the ti/ti-le/le genotype was developed from the cross of a strain with a black seed coat, green cotyledon, and the $t i / t i-l e / l e$ genotype and PI506592. A triple null genotype (lox1lox2lox3/lox1lox2lox3-ti/ti-le/le, free of lipoxygenase, KTI, and lectin proteins) with a black seed coat, green cotyledon, and a large seed size was developed from the cross of the lox1lox2lox3/lox1lox2lox3 genotype (black seed coat and green cotyledon) and the 
ti/ti-le/le genotype (black seed coat, green cotyledon, and large seed size). During the summer of 2016, $\mathrm{F}_{1}$ pollinations were made between the lox1lox2lox3/lox1lox2lox3-rs2/rs2 genotype (black seed coat and green cotyledon) and the lox1lox2lox3/lox1lox2lox3-ti/ti-le/le genotype (black seed coat, green cotyledon, and large seed size) to produce seeds with a tetra null allele (lox1lox2lox3/lox1lox2lox3-ti/ti-le/le-rs2/rs2, low content of stachyose, and free of lipoxygenase, KTI, and lectin proteins), a black seed coat, green cotyledon, and a large seed size. $F_{1}$ seeds obtained were planted on 20 February 2017 in the greenhouse and all $F_{1}$ plants were individually harvested and bulked. A total of $92 \mathrm{~F}_{2}$ seeds were obtained. Each seed was analyzed to screen for the genotype with a triple recessive allele (lox1lox2lox3/lox1lox2lox3-ti/ti-le/le (absence of lipoxygenase, KTI, and lectin proteins)). Among $92 \mathrm{~F}_{2}$ seeds, $9 \mathrm{~F}_{2}$ seeds possessing the triple null allele (lox1lox2lox3/lox1lox2lox3ti/ti-le/le) were obtained and were planted on 10 July 2018 in the University field. Nine $\mathrm{F}_{2}$ plants were individually harvested. Random $\mathrm{F}_{3}$ seeds of each $\mathrm{F}_{2}$ plant harvested were analyzed to select the $r s 2 r s 2$ genotype (low content of stachyose). Three $\mathrm{F}_{2}$ plant strains $\left(\mathrm{F}_{3}\right.$ seed) with the tetra null genotype (lox1lox2lox3/lox1lox2lox3-ti/ti-le/le-rs2/rs2) were selected. A random sample of $50 \mathrm{~F}_{3}$ seeds per strain were planted on 6 July 2019 in University field. One $\mathrm{F}_{3}$ plant strain was chosen based on plant type, maturing date, stem height, seed coat color, cotyledon color, seed quality, and seed weight. After harvesting, random $\mathrm{F}_{4}$ seeds were used to confirm recessive genotypes (lox1lox2lox3/lox1lox2lox3-ti/ti-le/lers2/rs2) for lipoxygenase, KTI, lectin, and stachyose components. The scheme for breeding of the tetra null genotype (lox1lox2lox3/lox1lox2lox3-ti/ti-le/le-rs2/rs2) with a black seed coat and green cotyledon is presented in Figure 1.

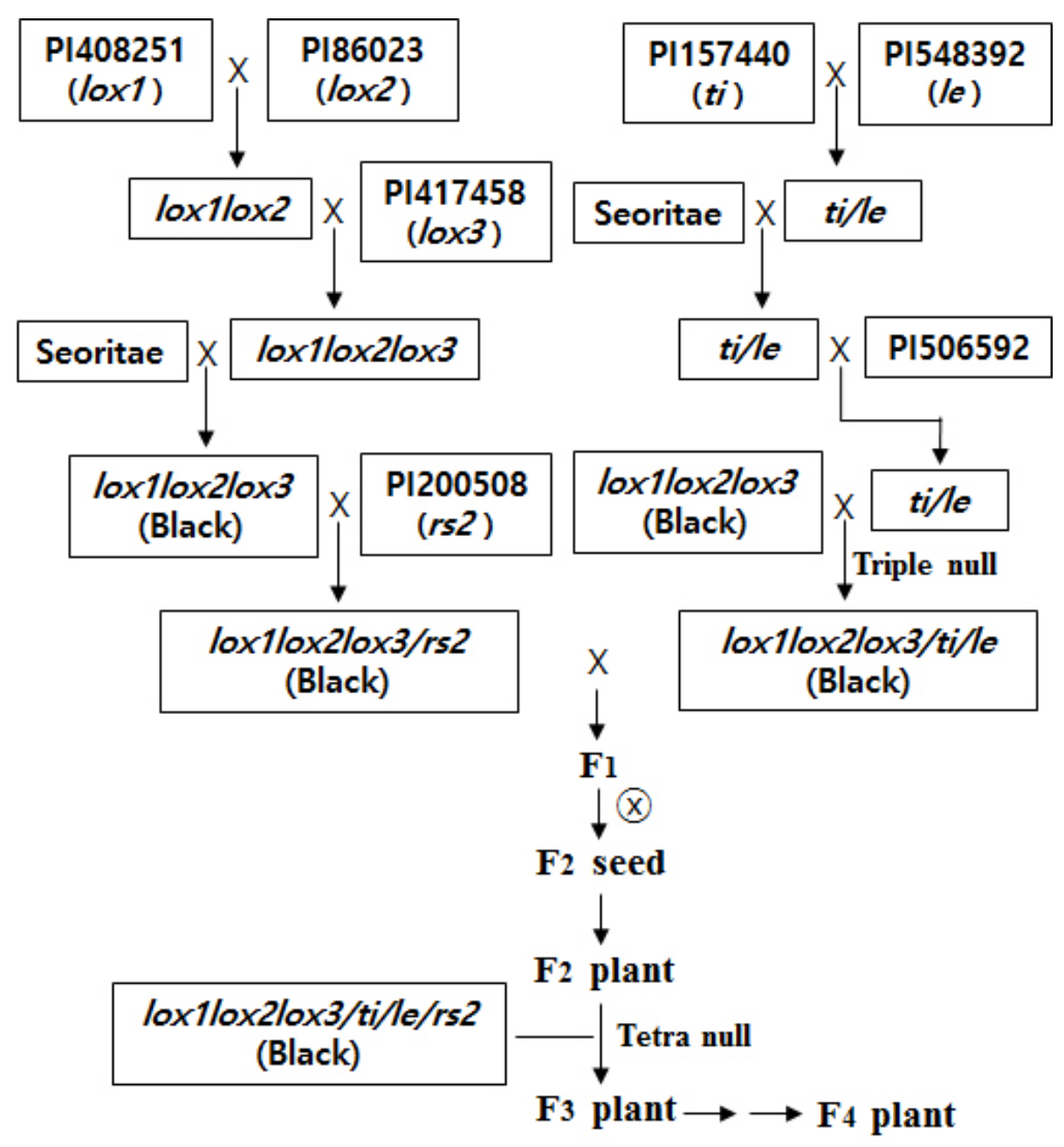

Figure 1. Scheme for development of a tetra null genotype (lox1lox2lox3/lox1lox2lox3-ti/ti-le/lers2/rs2) with a black seed coat and green cotyledon using eight soybean parents. 


\subsection{Agricultural Traits of Tetra Null Genotype}

A random $150 \mathrm{~F}_{4}$ seeds were planted on 9 July 2020 in University field. The experimental field design was a completely randomized design with three replications. The plots were two rows $3 \mathrm{~m}$ long spaced $0.65 \mathrm{~m}$ apart within the plot. The seeding rate was 25 seeds per row. Soil type was a silty clay loam. Soil $\mathrm{K}, \mathrm{Ca}, \mathrm{Mg}$, and $\mathrm{Na}$ averaged $0.46,8.84,2.83$, and $0.28 \mathrm{cmol}_{\mathrm{c}} / \mathrm{kg}$, respectively. Soil $\mathrm{pH}$ was 6.8 . Agronomic traits such as maturing date, stem height $(\mathrm{cm})$, 100-seed weight $(\mathrm{g})$, yield for breeding line (tetra null genotype), and check cultivar ('Chungja\#3', Lox1Lox2Lox3/Lox1Lox2Lox3-Ti/Ti-Le/Le-RS2/RS2, black seed coat, and green cotyledon) were recorded on the $\mathrm{F}_{4}$ plant generation. Mean values of stem height, 100-seed weight, and yield were compared by Duncan's multiple range test at the $5 \%$ level.

\subsection{Determination of Lipoxygenase Protein by SDS-PAGE}

Crude protein from random seeds of the check cultivar ('Chungja\#3') and breeding line was obtained to identify the presence $\left({ }^{\prime}+\right.$ ') or absence (' - ') of lipoxygenase protein. The fine powder samples of two materials were incubated for $30 \mathrm{~min}$ in $1 \mathrm{ml}$ of Tris- $\mathrm{HCl}, \mathrm{pH}$ 8.0, and $1.56 \% v / v \beta$-mercaptoethanol. Fifty microliters $(50 \mu \mathrm{l})$ of the supernatant through centrifugation was added to an equivalent amount of $5 \mathrm{X}$ sample buffer containing $1 \mathrm{M}$ Tris- $\mathrm{HCl}, \mathrm{pH} 6.8,50 \% v / v$ glycerol, $1.96 \% v / v \beta$-mercaptoethanol, and $10 \% w / v$ sodium dodecyl sulfate (SDS). The sample obtained was boiled at $97^{\circ} \mathrm{C}$ for $5 \mathrm{~min}$ and the sample was centrifuged. Two microliters $(2 \mu \mathrm{l})$ of the supernatant was loaded on a $12 \%$ acrylamide SDS polyacrylamide gel in electrophoresis medium gels (Owl Separation Systems Inc., Model: P9DS, Portsmouth, NH, USA). After electrophoresis at $120 \mathrm{~V}$ for $7 \mathrm{~h}$, gels were stained. For several hours, the gels were destained in destaining solution. Protein marker (Sigma Marker, Product Code: M4038, St. Louis, MO, USA) was used to identify the presence or absence of lipoxygenase protein $(97 \mathrm{kDa})$.

\subsection{Determination of KTI and Lectin Protein by Western Blot Analysis}

Proteins obtained from each $\mathrm{F}_{2}$ seed, check cultivar ('Chungja\#3'), and breeding line were separated by $10 \%$ or $12 \%$ SDS-PAGE and transferred onto an Immobilon-P membrane (PVDF, Millipore, Merck, Kenilwork, NJ, USA). After blocking for $2 \mathrm{~h}$ in TBS buffer containing $0.1 \%$ Tween 20, $20 \mathrm{mM}$ Tris (pH 7.5), $150 \mathrm{mM} \mathrm{NaCl}$, and $5 \%$ nonfat dried milk (Cell Signaling Technology, Danvers, MA, USA), the membrane was incubated with an antibody of KTI and lectin protein for $1 \mathrm{~h}$. The blot was incubated with a horseradish peroxidase conjugated secondary antibody after washing in TBS buffer. Using an enhanced chemiluminescence kit (Amersham, Buckinghamshire, UK), the complex was visualized. Presence or absence of KTI ( $21.5 \mathrm{kDa})$ and lectin $(120 \mathrm{kDa})$ proteins was determined visually. The ratio of segregation for presence or absence of KTI and lectin proteins was determined by Chi-square analysis.

\subsection{Stachyose Analysis}

Stachyose content was determined by a High-Performance Liquid Chromatograph (HPLC) method. Each seed sample from a single $F_{2}$ plant $\left(F_{3}\right.$ seed), the check cultivar ('Chungja\#3'), and the breeding line was ground into powder for HPLC analysis. Two hundred milligrams $(200 \mathrm{mg}$ ) of ground seed sample was extracted with $3 \mathrm{~mL}$ of acetone in a water bath for $2 \mathrm{~h}$ at $60^{\circ} \mathrm{C}$. The mixture was centrifuged for $5 \mathrm{~min}$ at $2000 \mathrm{rpm}$ to remove the fat. We added $1.9 \mathrm{~mL}$ of double distilled $\mathrm{H}_{2} \mathrm{O}$ to the defatted extract in a water bath for $2 \mathrm{~h}$ at $60^{\circ} \mathrm{C}$. After the water bath treatment, $0.1 \mathrm{~mL}$ of $1 \mathrm{M}$ 5-sulfosalicylic acid (5-SSA) was added to the mixture and it was placed overnight at $4{ }^{\circ} \mathrm{C}$. The mixture was centrifuged for $5 \mathrm{~min}$ at $3000 \mathrm{rpm}$. The supernatant was added to $0.8 \mathrm{~mL}$ of $\mathrm{ddH}_{2} \mathrm{O}$ and was centrifuged for $10 \mathrm{~min}$ at $12,000 \mathrm{rpm}$. After centrifugation, the supernatant was filtered through a $0.2 \mu \mathrm{m}$ membrane filter and stored at $4{ }^{\circ} \mathrm{C}$ prior to the HPLC analysis. Stachyose was analyzed using an Agilent 1100 series HPLC (Agilent Technologies, Waldbronn, Germany), an R1 Refractive Index Detector, and a Supelcogel 610-H-column $(30 \mathrm{~cm} \times 7.8 \mathrm{~mm}$ ID column, 
$9 \mu \mathrm{m}$, Supelco, Bellefonte, PA, 16823-0048 USA). The eluent solvent of $0.1 \% \mathrm{H}_{3} \mathrm{PO}_{3}$ was used, and HPLC conditions were a $10 \mu \mathrm{L}$ injection volume and a $0.6 \mathrm{~mL} / \mathrm{min}$ flow rate.

\section{Results}

\subsection{Inheritance of KTI and Lectin Proteins}

KTI protein of $21.5 \mathrm{kDa}$ and lectin protein of $120 \mathrm{kDa}$ were segregated in the $92 \mathrm{~F}_{2}$ seed generation (Table 2).

Table 2. Segregation for presence or absence of Kunitz trypsin inhibitor (KTI) and lectin proteins in the $\mathrm{F}_{2}$ seed generation derived from the cross of the lox1lox2lox3/lox1lox2lox3-Ti/Ti-Le/Le-rs2/rs2 parent and the lox1lox2lox3/lox1lox2lox3-ti/ti-le/le-RS2/RS2 parent.

\begin{tabular}{cccccc}
\hline \multirow{2}{*}{ KTI } & Lectin & \multicolumn{2}{c}{ Number of Seeds } & \multirow{2}{*}{$\begin{array}{c}\boldsymbol{2}^{\mathbf{2}} \text { Value } \\
\mathbf{( 9 : 3 : 3 : 1 )}\end{array}$} & $\boldsymbol{p}$ \\
\cline { 3 - 4 } & & Observed & Expected & & \\
Present & Present & 45 & 51.75 & & \\
Present & Absent & 18 & 17.25 & 3.13 & $0.5-0.1$ \\
Absent & Present & 20 & 17.25 & & \\
Absent & Absent & 9 & 5.79 & & \\
\hline
\end{tabular}

Among the $92 \mathrm{~F}_{2}$ seeds, $63 \mathrm{~F}_{2}$ seeds showed KTI protein and $29 \mathrm{~F}_{2}$ seeds did not show KTI protein. Lectin protein existed in 65 F2 seeds and 27 F2 seeds did not show lectin protein. The segregation ratio for the presence or absence of KTI and lectin proteins in the $F_{2}$ seed generation was fitted to an expected 3:1 ratio $\left(\chi^{2}=2.09\right.$ for KTI and 0.93 for lectin proteins). Between KTI protein and lectin protein, the segregation ratios of 45 Ti_Le_: 18 Ti_lele: 20 titiLe_: 9 titilele were observed $\left(\chi^{2}=3.13, p=0.5-0.1\right)$.

\subsection{Content of Stachyose for $F_{2}$ Plants with Triple Null Allele}

Stachyose content for nine $F_{2}$ plants was obtained using random $F_{3}$ seeds of each $F_{2}$ plant harvested (Table 3).

Table 3. Content of stachyose for nine $\mathrm{F}_{2}$ plants $\left(\mathrm{F}_{3}\right.$ seeds) with the triple null allele (lox1lox2lox3/ lox1lox2lox3-ti/ti-le/le).

\begin{tabular}{|c|c|c|}
\hline Number of $F_{2}$ Plants & Stachyose (g/kg) & Genotype Expected \\
\hline 1 & 12.71 & $R S 2_{-}$ \\
\hline 2 & 13.14 & $R S 2_{-}$ \\
\hline 3 & 3.26 & $r s 2 r s 2$ \\
\hline 4 & 12.83 & $R S 2_{-}$ \\
\hline 5 & 3.17 & $r s 2 r s 2$ \\
\hline 6 & 3.53 & $r s 2 r s 2$ \\
\hline 7 & 14.33 & $R S 2_{-}$ \\
\hline 8 & 13.91 & $R S 2_{-}$ \\
\hline 9 & 12.51 & $\mathrm{RS}_{2}$ \\
\hline
\end{tabular}

The stachyose content of the nine $F_{2}$ plants was 3.17-14.33 g/ $\mathrm{kg}$. Three $F_{2}$ plants showed a low stachyose content of $3.26,3.17$, and $3.53 \mathrm{~g} / \mathrm{kg}$. One $F_{3}$ plant strain from three $\mathrm{F}_{2}$ plants was chosen based on agronomical traits.

\subsection{Confirmation of Tetra Null Line}

Random $\mathrm{F}_{5}$ seeds were used to confirm the absence of lipoxygenase, KTI, and lectin proteins (Figure 2). 

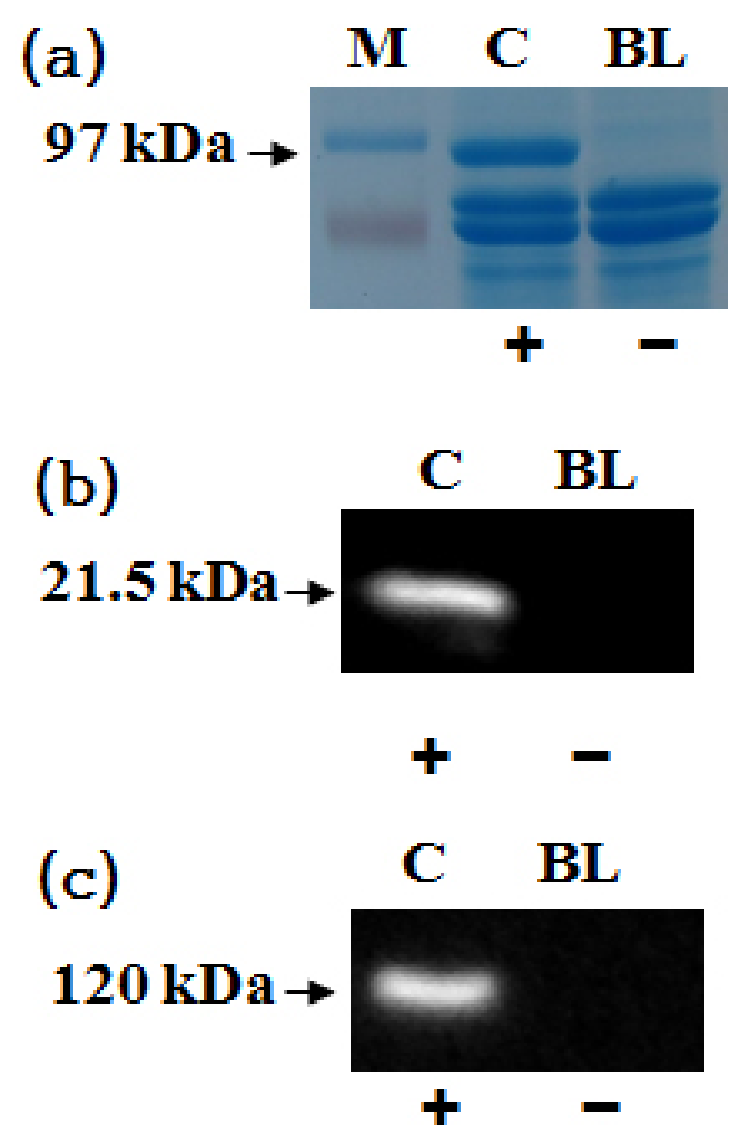

Figure 2. Determination of lipoxygenase protein (a), Kunitz trypsin inhibitor (KTI) protein (b), and lectin protein (c). M, marker; C, 'Chungja\#3' (Lox1Lox2Lox3/Lox1Lox2Lox3-Ti/Ti-Le/Le-RS2/RS2); $\mathrm{BL}$, tetra null line (lox1lox2lox3/lox1lox2lox3-ti/ti-le/le-rs2/rs2). +, -: presence and absence of lipoxygenase, KTI, and lectin proteins, respectively.

Proteins of lipoxygenase, KTI, and lectin were not observed in the mature $\mathrm{F}_{5}$ seed of the breeding line (BL). However, these three proteins were observed in the seed of the 'Chungja\#3' (Lox1Lox2Lox3/Lox1Lox2Lox3-Ti/Ti-Le/Le-RS2/RS2) cultivar.

\subsection{Agronomic Traits of Tetra Null Line}

Some agronomic traits of the breeding line are shown in Table 4.

Table 4. Agronomic performance of cultivar 'Chungja\#3' and the breeding line under field conditions during 2020.

\begin{tabular}{ccccccc}
\hline $\begin{array}{c}\text { Cultivar/Breeding } \\
\text { Line }\end{array}$ & Planting Date & Maturing Date & $\begin{array}{c}\text { Stem Height } \\
(\mathbf{c m})\end{array}$ & $\begin{array}{c}\text { Seed Weight } \\
\mathbf{( g / 1 0 0 ~ S e e d s )}\end{array}$ & $\begin{array}{c}\text { Stachyose } \\
(\mathbf{g} / \mathbf{k g})\end{array}$ & $\begin{array}{c}\text { Yield } \\
(\mathbf{T o n} / \mathbf{h a})\end{array}$ \\
\hline ‘Chungja\#3' & 9 June & 18 October & $50.7^{\mathrm{a}} 1$ & $33.3^{\mathrm{a}}$ & $12.64^{\mathrm{a}}$ & $2.10^{\mathrm{a}}$ \\
Breeding Line & 9 June & 16 October & $52.3^{\mathrm{a}}$ & $35.2^{\mathrm{b}}$ & $3.30^{\mathrm{b}}$ & $2.50^{\mathrm{b}}$ \\
\hline
\end{tabular}

${ }^{1}$ Same letters in the column are not significant at the $5 \%$ significance level by Duncan's multiple range tests.

The breeding line developed in this study has purple flowers, a determinate growth habit, and brown pods at maturity. The breeding line matured on October 16, which is 2 days earlier than 'Chungja\#3'. The stem height of the breeding line was $52.3 \mathrm{~cm}$, while that of the check cultivar was $50.7 \mathrm{~cm}$. The 100-seed weight of the breeding line was $35.2 \mathrm{~g}$ larger than that of 'Chungja\#3' (33.3 g). The stachyose content of the breeding line was $3.30 \mathrm{~g} / \mathrm{kg}$, which was much less than the 12.64 of 'Chungja\#3'. The yield of the breeding line was 2.50 Ton/ha-much higher than that of 'Chungja\#3' (2.10 Ton/ha). The plant type 
harvested and seeds of the tetra null strain (lox1lox2lox3/lox1lox2lox3-ti/ti-le/le-rs2/rs2) are shown in Figure 3.
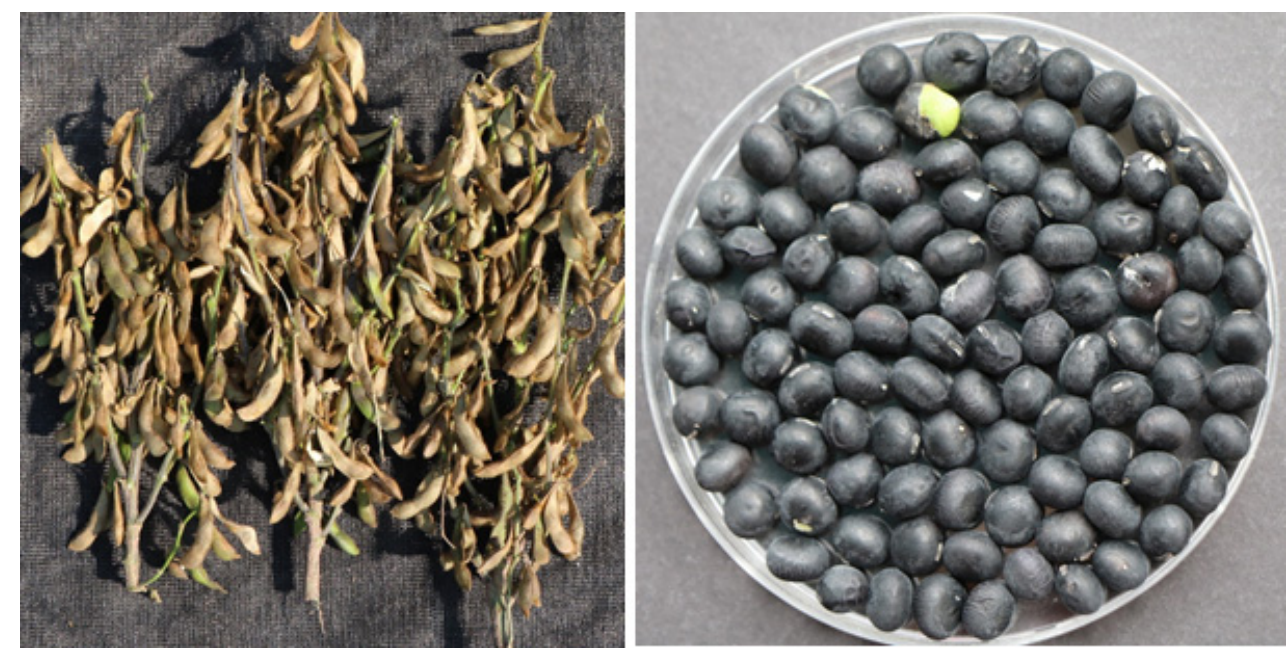

Figure 3. Appearance of the $\mathrm{F}_{4}$ plant and $\mathrm{F}_{5}$ seeds with the tetra null allele (lox1lox2lox3/lox1lox2lox3ti/ti-le/le-rs2/rs2), a black seed coat, and green cotyledon.

The seed of the breeding line has a black hilum and a black seed coat color. The cotyledon color of mature seeds is green.

\section{Discussion}

In Asia, soybean cultivars with a black seed coat, green cotyledon, and large seed size have been cultivated for a long time. Anthocyanins that are abundant in the seed coat of black soybean are known to have many pharmacological effects. Lipoxygenase, Kunitz trypsin inhibitor (KTI), lectin, and stachyose components that exist in the raw mature seeds of black soybean have been considered as antinutritional and allergenic factors $[30,31]$. The genetic removal of these factors is needed to modify the food processing properties and to improve the nutritional values of soybeans. Moreover, the variety of the tetra recessive allele (absence of lipoxygenase, KTI, and lectin proteins, low content of the stachyose component) enhances the utilization of soybean foods. To obtain seeds possessing the tetra null allele (lox1lox2lox3/lox1lox2lox3-ti/ti-le/le-rs2/rs2), two parents (the lox1lox2lox3/lox1lox2lox3-rs2/rs2 genotype and the lox1lox2lox3/lox1lox2lox3ti/ti-le/le genotype) were developed using eight parents (Table 1, Figure 1). A total of 92 $\mathrm{F}_{2}$ seeds were obtained from the cross of these two parents. KTI and lectin proteins were segregated in the $\mathrm{F}_{2}$ seed generation (Table 2). The segregation ratio for the presence or absence of KTI and lectin proteins was fitted to an expected 3:1 ratio $\left(\chi^{2}=2.09\right.$ for KTI and 0.93 for lectin proteins). This result substantiates previous results that the presence or absence of KTI and lectin proteins is controlled by a single gene $[13,19]$. Independent inheritance between KTI protein and lectin protein was observed $\left(\chi^{2}=3.13\right)$. This result was found to be consistent with previous results, which show that both $T i$ and Le alleles were inherited independently $[13,20,21,29]$. The Le allele that was inherited independently with the Ti allele in the $\mathrm{F}_{2}$ population consisted of 24 plants [21]. The $\mathrm{Ti}$ and $\mathrm{Le}$ alleles were inherited independently in the $\mathrm{F}_{2}$ population with 96 plants [13]. Lee et al. [20] reported that the $\mathrm{Ti}$ and Le alleles were independently inherited in a $173 \mathrm{~F}_{2}$ seed generation. Additionally, Choi et al. [29] observed that Ti and Le alleles were independently inherited in an $\mathrm{F}_{2}$ seed generation consisting of 179 seeds. Among nine $\mathrm{F}_{2}$ plants with the triple null allele (lox1lox2lox3/lox1lox2lox3-ti/ti-le/le), three $\mathrm{F}_{2}$ plants showed a low stachyose content ( $r s 2 r s 2$ genotype). The stachyose content of three $\mathrm{F}_{2}$ plants was $3.17-3.53 \mathrm{~g} / \mathrm{kg}$ (Table 3). This result suggests that stachyose content was controlled by a single recessive gene [26]. Three $F_{2}$ plants possessing a 
triple null allele $(t i / t i-l e / l e-r s 2 / r s 2)$ were selected. In previous research, two $\mathrm{F}_{2}$ seeds possessing a triple null allele $(t i / t i-l e / l e-p 34 / p 34)$ were selected from $150 \mathrm{~F}_{2}$ seeds [22]. Absence of lipoxygenase, KTI, and lectin proteins in $\mathrm{F}_{5}$ seeds of the tetra null line (lox1lox2lox3/lox1lox2lox3-ti/ti-le/le-rs2/rs2 genotype) developed in this study was confirmed (Figure 2).

Agricultural traits of the tetra null soybean line are shown in Table 4. In spite of low content of stachyose and the absence of lipoxygenase, KTI, and lectin proteins, the tetra null soybean line germinated, grew, flowered, and reproduced normally under field conditions when compared with cultivar 'Chungja\#3'. Seeds with the lox1lox2lox3/lox1lox2lox3 genotype (free of lipoxygenase protein) have been demonstrated to develop into normal plants without defects [10]. Schmidt et al. [22] observed that plants possessing triple null alleles (ti/ti-le/le-p34/p34) flowered and produced seeds without any overt differences in comparison to the standard 'Williams 82 ' cultivar. Significant differences were observed for seed weight ( $\mathrm{g} / 100$ seeds), content of stachyose $(\mathrm{g} / \mathrm{kg})$, and yield (Ton/ha) between the tetra null soybean line and 'Chungja\#3' cultivar. These results indicate that the tetra null soybean line with a black seed coat, green cotyledon, and large seed size had no impact on these agronomic traits (Figure 3). These results suggest that accumulation of recessive alleles for the Lox1, Lox2, Lox3, Ti, Le, and RS2 genes result in a soybean cultivar with significantly reduced allergy and antinutritional factors. In this study, quantitative traits such as yield, stem height, and seed weight for the tetra null line were obtained in a single location with three replications (Table 4). However, it is considered that field experiments with years and locations should be carried out for accurate evaluation in the future. For the breeding line, generation advancement should be conducted and qualitative traits like flower color, pubescence color, and pod color should be checked. Additionally, repeated experiments on quantitative traits such as maturing date, stem height, seed weight, stachyose content, protein content, oil content, and yield should be further conducted. Studies on the quality and functionality of foods made from seeds of the tetra null line should be conducted and the level of allergens present in foods must be investigated. The newly improved strain in this research will be used to develop a new soybean cultivar with a black seed coat, green cotyledon, high quality, and function.

\section{Conclusions}

Eight parents were used to breed a new soybean strain with a black seed coat color, a green cotyledon color, and tetra recessive alleles (lox1lox2lox3/lox1lox2lox3-ti/ti-le/lers2/rs2) for lipoxygenase, KTI, lectin, and stachyose components. From segregation for KTI and lectin proteins in an $\mathrm{F}_{2}$ seed generation, a ratio of 45 Ti_Le_: 18 Ti_lele: 20 titiLe_: 9 titilele was observed $\left(\chi^{2}=3.13, p=0.5-0.1\right)$. Nine $F_{2}$ seeds possessing a triple null allele (lox1lox2lox3/lox1lox2lox3-ti/ti-le/le) were obtained. Three $\mathrm{F}_{2}$ plants showed a low stachyose content of $3.26,3.17$, and $3.53 \mathrm{~g} / \mathrm{kg}$. One $\mathrm{F}_{3}$ strain with proper agronomical traits was selected. Proteins of lipoxygenase, KTI, and lectin were not observed in the mature $\mathrm{F}_{5}$ seeds of the tetra null line. The soybean line with a black seed coat, green cotyledon, large seed size, and tetra recessive allele has purple flowers, a determinate growth habit, and brown pods at maturity. The breeding line matured in October 16, which is 2 days earlier than 'Chungja\#3'. The stem height of the breeding line was $52.3 \mathrm{~cm}$, while that of the check cultivar was $50.7 \mathrm{~cm}$. The 100-seed weight of the breeding line was $35.2 \mathrm{~g}$, larger than that of 'Chungja\#3' (33.3 g). The stachyose content of the breeding line was $3.30 \mathrm{~g} / \mathrm{kg}$, which was much less than the 12.64 of 'Chungja\#3'. The yield of the breeding line was 2.50 Ton/ha—much higher than that of 'Chungja\#3' (2.10 Ton/ha).

Author Contributions: S.W.C., J.E.K., S.K.L., S.L., and J.I.C. were involved in the experimental design, crossing, protein analysis, planting, harvesting, data collection, and interpretation as well as the write-up of this research. All authors have read and agreed to the published version of the manuscript. 
Funding: This research was supported by the Basic Science Research Program through the National Research Foundation of Korea (NRF) funded by the Ministry of Education (NRF2018R1D1A1B07045483) and the Korea Institute of Planning and Evaluation for Technology in Food, Agriculture and Forestry (Research number: 119011-3).

Informed Consent Statement: Not applicable.

Data Availability Statement: Not applicable.

Conflicts of Interest: The authors declare that there is no competing interest.

\section{References}

1. Burns, J.; Gardner, P.T.; O’Neil, J.; Crawford, S.; Morecroft, I.; McPhail, D.B.; Lister, C.; Matthews, D.; MacLean, M.R.; Lean, M.E.; et al. Relationship among antioxidant activity, vasodilation capacity and phenolic contents of red wines. J. Agric. Food Chem. 2000, 48, 220-230. [CrossRef]

2. Kim, H.J.; Tsoy, I.; Park, J.M.; Chung, J.I.; Shin, S.C.; Chang, K.C. Anthocyanins from soybean seed coat inhibit the expression of TNF-a-induced genes associated with ischemia/reperfusion in endothelial cell by NF-jB-dependent pathway and reduce rat myocardial damages incurred by ischemia and reperfusion in vivo. FEBS Lett. 2006, 580, 1391-1397. [CrossRef] [PubMed]

3. Kamei, H.; Kojima, T.; Hasegawa, M.; Koide, T.; Umeda, T.; Yukawa, T.; Terabe, K. Suppression of tumor cell growth by anthocyanins in vitro. Cancer Investig. 1995, 13, 590-594. [CrossRef] [PubMed]

4. Axelrod, B.; Cheesbrough, T.; Laakso, S. Lipoxygenase from soybeans. Methods Enzymol. 1981, 71, 441-451.

5. Hildebrand, D.F.; Hymowitz, T. Two soybean genotypes lacking lipoxygenase-1. J. Am. Oil Chem. Soc. 1981, 58, 583-586. [CrossRef]

6. Hildebrand, D.F.; Hymowitz, T. Inheritance of Lipoxygenase-1 Activity in Soybean Seeds. Crop Sci. 1982, 22, 851-853. [CrossRef]

7. Davies, C.S.; Nielsen, N.C. Genetic Analysis of a Null-Allele for Lipoxygenase-2 in Soybean. Crop. Sci. 1986, $26,460-463$. [CrossRef]

8. Kitamura, K.; Kumagai, T.; Kikuchi, A. Inheritance of lipoxygenase-2 and genetic relationships among genes for lipoxygenase-1, -2 and -3 isozymes in soybean seeds. Jpn. J. Breed. 1985, 35, 413-420. [CrossRef]

9. Kitamura, K.; Davies, C.S.; Kaizuma, N.; Nielsen, N.C. Genetic analysis of a null-allele for lipoxygenase-3 in soybean seeds. Crop Sci. 1983, 23, 924-927. [CrossRef]

10. Hajika, M.; Kitamura, K.; Igita, K.; Nakazawa, Y. Genetic relationships among the genes for lipoxygenase-1, -2 and -3 isozymes in soybean [Glycine max (L.) Merrill] seed. Jpn. J. Breed. 1992, 42, 787-792. [CrossRef]

11. Chung, J.I. A new cultivar "Gaechuck\#1": Black soybean cultivar with lipoxygenase2,3-free, Kunitz trypsin inhibitor-free and green cotyledon. Korean J. Breed. Sci. 2009, 41, 603-606.

12. Kunitz, M. Crystallization of a soybean trypsin inhibitor from soybean. Science 1945, 101, 668-669. [CrossRef] [PubMed]

13. Orf, J.H.; Hymowitz, T. Inheritance of the absence of the Kunitz trypsin inhibitor in seed protein of soybeans. Crop Sci. 1979, 19, 107-109. [CrossRef]

14. Hymowitz, T.; Hadley, H.H. Inheritance of a trypsin inhibitor variant in seed protein of soybeans. Crop Sci. 1972, 12, 197-198. [CrossRef]

15. Singh, L.; Wilson, C.M.; Hadley, H.H. Genetic differences in soybean trypsin inhibitors separated by disc electrophoresis. Crop Sci. 1969, 9, 489-491. [CrossRef]

16. George, M.; Bhide, S.; Thengane, R.; Hosseini, G.; Manjaya, J. Identification of low lectin mutants in soybean. Plant Breed. 2008, 127, 150-153. [CrossRef]

17. Pull, S.P.; Pueppke, S.G.; Hymowitz, T.; Orf, J.H. Soybean lines lacking the 120,000 daltons seed lectin. Science 1978, 200 , 1277-1279. [CrossRef]

18. Schulze, H.; Saini, H.S.; Huisman, J.; Hessing, M.; Berg, W.; Verstegen, M.W.A. Increased nitrogen secretion by inclusion of soya lectin in the diets of pigs. J. Sci. Food Agric. 1995, 69, 501-510. [CrossRef]

19. Orf, J.H.; Hymowitz, T.; Pull, S.P.; Pueppke, S.G. Inheritance of a soybean seed lectin. Crop Sci. 1978, 18, 899-900. [CrossRef]

20. Lee, K.J.; Park, M.S.; Sung, M.K.; Kim, M.S.; Chung, J.I. Inheritance between Le gene and Ti gene in soybean (Glycine max L.). Korean J. Breed. Sci. 2008, 40, 97-100.

21. Moraes, R.M.A.; Soares, T.C.B.; Colombo, L.R.; Salla, M.F.S.; Barros, J.G.A.; Piovesan, N.D.; Barros, E.G.; Moreira, M.A. Assisted selection by specific DNA markers for genetic elimination of the kunitz trypsin inhibitor and lectin in soybean seeds. Euphytica 2006, 149, 221-226. [CrossRef]

22. Schmidt, M.A.; Hymowitz, T.; Herman, E.M. Breeding and characterrization of soybean triple null; a stack of recessive alleles of Kunitz trypsin inhibitor, soybean agglutinin, and P34 allergen nulls. Plant Breed. 2015, 134, 310-315. [CrossRef]

23. Geater, C.W.; Fehr, W.R.; Wilson, L.A. Association of soy-bean seed traits with physical properties of natto. Crop Sci. 2000, 40, 1529-1534. [CrossRef]

24. Hymowitz, T.; Collins, F.I.; Panezner, J.; Walker, W.M. Relationship between the content of oil, protein, and sugar in soybean seed. Agron. J. 1972, 64, 613-616. [CrossRef] 
25. Hata, Y.; Yamamoto, M.; Nakajima, K. Effects of soybean oligosaccharides on human digestive organs: Estimation of fifty percent effective dose and maximum non- effective dose based on diarrhea. J. Clin. Biochem. Nutr. 1991, 10, 135-144. [CrossRef]

26. Skoneczka, J.A.; Saghai Maroof, M.A.; Shang, C.; Buss, G.R. Identification of candidate gene mutation associated with low stachyose phenotype in soybean lines PI200508. Crop Sci. 2009, 49, 247-255. [CrossRef]

27. Dierking, E.C.; Bilyeu, K.D. Association of a soybean raffinose synthase gene with low raffinose and stachyose seed Phenotype. Plant Genome. 2008, 1, 135-145. [CrossRef]

28. Neus, J.D.; Fehr, W.R.; Schnebly, S.R. Agronomic and seed characteristics of soybean with reduced raffinose and stachyose. Crop Sci. 2005, 45, 589-592. [CrossRef]

29. Choi, S.W.; Han, S.J.; Sung, M.K.; Chung, J.I. Breeding of black soybean line with ti and le allele. Plant Breed. Biotech. 2016, 4, 170-175. [CrossRef]

30. Liener, I.E. Possible adverse effects of soybean anticarcinogens. J. Nutr. 1995, 125, 744-750.

31. Robinson, D.S.; Wu, Z.; Domoney, C.; Casey, R. Lipoxygenases and the quality of foods. Food Chem. 1995, 54, 33-43. [CrossRef] 